\title{
KOMUNIKASI PEREMPUAN PEKERJA DALAM MEMBINA KELUARGA SEJAHTERA BURUH PABRIK DI JEMBER
}

\author{
Mukni'ah \\ Dosen Pascasarjana Institut Agama Islam Negeri Jember \\ mukniah@gmail.com
}

\begin{abstract}
This study aims to demonstrate the role of female workers (laborers) at PT Mangli Djaya Raya Petung Village, Bangsalsari District, Jember Regency in fostering a prosperous family, in regard to women's role both as a wife and mother. The background of the study was nowadays women have equal opportunities regarding their roles in a community. Following by emancipation of women, every woman could do what are commonly done by men, for instance, career. In this case, it is interesting to examine on how those career women roled in their work while they still manage in making a prosperous family. The study used qualitative approach through a case study. The data collection techniques used observation, interview and documentation. Interactive data analysis used several steps including data reduction, data presentation and drawing conclusion.
\end{abstract}

Keywords: female workers, prosperous families, careers

\begin{abstract}
Abstrak
Penelitian ini bertujuan untuk mendeskripsikan peran para perempuan pekerja (buruh) di PT Mangli Djaya Raya Desa Petung Kecamatan Bangsalsari Kabupaten Jember dalam membina keluarga sejahtera, baik dalam perannya sebagai istri maupun sebagai ibu. Penelitian ini dilakukan dilatarbelakangi fakta bahwa pada zaman modern saat ini, perempuan mendapatkan kesempatan yang sama dalam perannya di masyarakat. Dengan adanya emansipasi wanita, setiap perempuan dapat melakukan apa yang umum dilakukan oleh laki-laki, bekerja contohnya. Dalam hal ini menarik untuk diteliti bagaimana peran para perempuan pekerja tersebut di tengah kesibukannya bekerja, tetap dapat melakukan perannya dalam menciptakan keluarga yang sejahtera. Pendekatan yang digunakan dalam penelitian ini adalah kualitatif dengan jenis penelitian studi kasus. Teknik pengunpulan data yaitu dengan observasi, wawancara dan dokumentasi. Analisis data secara interaktif, dengan langkah-langkah yaitu reduksi data, penyajian data dan penarikan kesimpulan.
\end{abstract}

Kata kunci: perempuan pekerja, keluarga sejahtera, buruh 
INJECT (Interdisciplinary Journal of Communication), Vol.3, No.1, Juni 2018: h. 23-38

\section{Pendahuluan}

Peran dan tugas perempuan dalam keluarga secara garis besar dibagi menjadi beberapa hal yaitu sebagai ibu, istri, dan pekerja (karier). Pada masa ini, tidak sulit untuk menemukan perempuan yang dengan segenap kemampuannya, bersedia meluangkan waktu untuk bekerja di luar rumah, serta mendapatkan nafkah secara profesional. Perempuan yang disebut memiliki peran ganda adalah perempuan yang sudah menikah dan telah mempunyai anak. Perempuan ini dalam kehidupan sehari-hari dituntut untuk mampu melaksanakan dua peran, sehingga bagi mereka tidak hanya mempunyai tanggung jawab di dalam rumah, tetapi juga di luar rumah. Namun, mayoritas keyakinan masyarakat menyatakan bahwa pekerjaan perempuan harus dibatasi pada ruang domestik (di dalam rumah) saja, sedangkan laki-laki pada ruang publik (di luar rumah).

Pengalaman dalam kehidupan menunjukkan bahwa membangun keluarga itu mudah, namun memelihara dan membina maupun menciptakan keluarga hingga mencapai taraf kebahagiaan dan kesejahteraan yang selalu didambakan oleh setiap pasangan suami istri alangkah sukarnya. Keluarga sejahtera yang berintikan ketenteraman, kedamaian, dan ketenangan hidup merupakan harapan dan tujuan hidup dari sebuah perkawinan. Untuk mewujudkan sebuah keluarga yang sejahtera tentu saja memerlukan usaha yang keras, konsisten dan berkesinambungan.

Lebih dari itu untuk mewujudkan keluarga bahagia dan sejahtera maka perlu adanya perkawinan sebagaimana tertera dalam UU tentang perkawinan bab 1 ayat 1 yang berbunyi: "Perkawinan ialah ikatan lahir batin antara seorang pria dengan seorang wanita sebagai suami istri dengan tujuan membentuk keluarga (rumah tangga) yang bahagia dan kekal berdasarkan Ketuhanan Yang Maha Esa" (Sudarsono, 1991:309).

Dalam UU tersebut jelas bahwa keberadaan keluarga itu tidak luput dengan adanya kebesaran Allah Swt. yang telah memberikan perintah bagi setiap makhluk-Nya untuk melaksanakan perkawinan sebagai tanda 
rasa syukur terhadap-Nya, sebagaimana firman Allah Swt dalam AlQur'an yang berbunyi:

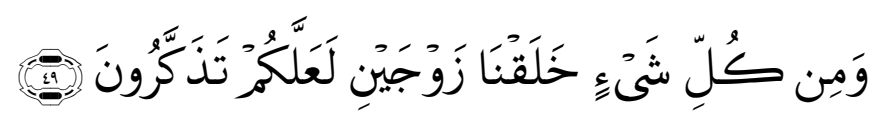

Artinya: "Dan segala sesuatu Kami ciptakan berpasang-pasangan supaya kamu mengingat kebesaran Allah." (QS. Surat Adz-Dzariyat:49)

Sejalan dengan ayat di atas, jelas bahwa Allah Swt. menciptakan makhluk-Nya secara berpasang-pasagan. Hal ini mempunyai tujuan untuk mewujudkan suatu keluarga yang bahagia. Perempuan yang memasuki fase perkawinan mempunyai peranan yang penting dalam kehidupan suatu keluarga, baik perannya bagi suami maupun anak-anaknya. Seorang istri atau ibu berkewajiban untuk melayani suami dan anak dalam semua aspek yang ada dalam kehidupan keluarganya. Kewajiban istri sebagai ibu tidak hanya berbelanja, memasak, mencuci, berdandan, mengatur keuangan, dan melahirkan, serta merawat anak, akan tetapi seorang ibu mempunyai peran yang lebih dominan dalam kehidupan suatu keluarga dibandingkan dengan peran suami.

Seperti yang telah tercantum di dalam UU perkawinan No. 1 Tahun 1974 pasal 31 ayat 3 yang berbunyi "Suami adalah kepala keluarga dan istri adalah ibu rumah tangga" (Sudarsono, 1991:309). Dengan demikian seorang suami menjadi kepala keluarga yang memimpin, membimbing dan melindungi keluarga dari gangguan lahir dan batin, serta mencari nafkah dan keperluan lainnya untuk anak dan istri. Begitu juga dengan seorang isteri sebagai ibu rumah tangga mempunyai kewajiban membantu suami dalam mempertahankan rumah tangga, mengatur segala keperluan rumah tangga, memperhatikan pendidikan anak, mengatur keuangan sehingga terjadi keselarasan antara pendapatan dan kebutuhan rumah tangga.

Pada dasarnya menurut Undang-Undang Perkawinan, suami atau laki-laki adalah kepala keluarga yang memimpin, membimbing dan 
melindungi keluarga dari gangguan lahir dan batin, serta mencari nafkah dan keperluan lainnya untuk anak dan istri, tetapi dalam ajaran Islam justru dapat dipahami bahwa peran seperti ini sebenarnya merupakan sesuatu yang tidak mutlak, dan bisa digantikan oleh istri, karena pada realitanya suatu saat suami atau laki-laki sedang tidak mampu melaksanakan kewajibannya sebagai suami entah karena sakit atau karena Allah memberikan nasib pada dia kurang menguntungkan dibanding perempuan sebagai istrinya, maka istripun dapat mengambil peran sebagai pencari nafkah dan melindungi keluarganya, karena Islam melarang menelantarkan anak dan keluarga. Al-Qur'an surat An-Nahl ayat 97:

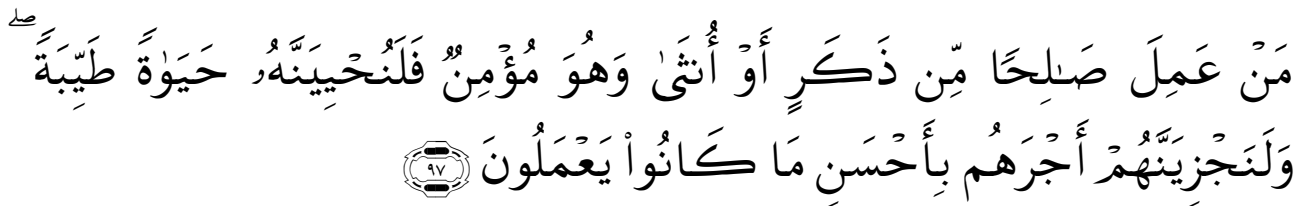

Artinya "Barangsiapa yang mengerjakan amal saleh, baik laki-laki maupun perempuan dalam Keadaan beriman, Maka Sesungguhnya akan Kami berikan kepadanya kehidupan yang baik dan Sesungguhnya akan Kami beri Balasan kepada mereka dengan pahala yang lebih baik dari apa yang telah mereka kerjakan". (QS. Surat An-Nahl:97).

Pada zaman modern saat ini, seorang ibu dituntut untuk kreatif, sabar dalam mencapai kesejahteraan keluarga. Banyak hal yang telah dilakukan istri sebagai ibu pekerja dalam membantu ekonomi keluarga dengan cara berwirausaha, bekerja di perusahaan swasta maupun pemerintah, di sinilah terlihat bahwa seorang ibu sangat berperan dalam ekonomi keluarga guna mencapai keluarga yang sejahtera. Ibu dapat berperan ganda di samping tugas pokoknya sebagai pengurus rumah tangga, juga membantu perekonomian keluarga yang tentu dengan izin suaminya agar tidak menimbulkan konflik kemudian hari.

Begitu pula yang terjadi pada istri atau ibu yang ada di Desa Petung Kecamatan Bangsalsari Kabupaten Jember. Mayoritas warga Desa Petung menjadi buruh di pabrik PT Mangli Djaya Raya (MDR) 
dengan jam kerja dari pukul 07.00 hingga pukul 16.00. Para ibu rumah tangga ini berperan dalam membantu perekonomian keluarga dengan menjadi buruh di pabrik tersebut.

Ibu rumah tangga ini menganggap bahwa mereka dapat meringankan beban suami dalam mencari nafkah melalui bekerja di pabrik sebagai buruh tanpa meninggalkan kewajibannya sebagai pengurus rumah tangga. Mereka harus bisa membagi waktu untuk anak dan keluarganya. Mereka dituntut untuk tetap mengurus rumah tangga, memperhatikan pendidikan anak di samping membantu perekonomian keluarga. $\mathrm{Hal}$ itu mereka lakukan untuk mencapai keluarga yang makmur sejahtera sehingga mereka dapat memenuhi kebutuhan pendidikan anak dengan baik.

\section{Permasalahan}

Dari latar belakang di atas yang menjadi rumusan masalah adalah bagaimana peran perempuan pekerja sebagai istri dalam membina keluarga sejahtera ? dan bagaimana peran perempuan pekerja sebagai ibu dalam membina keluarga sejahtera?

\section{Keluarga Sejahtera}

Keluarga sejahtera secara garis besar adalah keluarga yang dibentuk berdasarkan atas perkawinan yang sah, mampu memenuhi kebutuhan hidup spiritual dan materil yang layak, bertakwa kepada Tuhan Yang Maha Esa, memiliki hubungan yang serasi, selaras dan seimbang antar anggota dan antara keluarga dengan masyarakat dan lingkungan (Djamarah, 2004:115).

Terbentuknya keluarga karena adanya perkawinan antara dua individu yang berlainan jenis. Jadi, keluarga yang baru dibentuk hanya terdiri dari suami dan istri yang selanjutnya akan disusul oleh anggota baru yaitu anak. Peran istri dalam membina keluarga sejahtera bukan sesuatu 
yang berdiri sendiri, peran dan tanggung jawab tersebut merupakan bagian yang tidak terpisahkan dari peran dan tanggung jawab suami. Keduanya saling melengkapi dan saling mendukung dengan terbentuknya keluarga sejahtera.

\section{Metode Penelitian}

Metode penelitian yang digunakan adalah pendekatan kualitatif yaitu mendeskripsikan tentang suatu aktivitas, dengan fokus pada peran perempuan pekerja dalam pembinaan keluarga sejahtera baik sebagai istri maupun ibu dalam keluarga. Dalam subjek penelitian ini berupa individu, kelompok, lembaga maupun masyarakat (Prastowo, 2011: 127). Dalam penelitian ini, subjek penelitiannya yaitu para perempuan pekerja (buruh) pabrik pengeringan dan pengemasan tembakau PT Mangli Djaya Raya Desa Petung Kecamatan Bangsalsari Kabupaten Jember. Penelitian ini dilakukan di Desa Petung Kecamatan Bangsalsari Kabupaten Jember. Pengumpulan data dalam penelitian ini menggunakan teknik observasi, wawancara, dan dokumentasi. Langkah analisis data yang dilakukan menggunakan model Miles dan Huberman, yaitu: data reduction, data display, dan conclusion drawing/verification".

\section{Peran Perempuan Pekerja Sebagai Istri dalam Membina Keluarga Sejahtera}

Pada hakikatnya perempuan yang memiliki peran sebagai isteri merupakan makhluk terpilih untuk mendampingi suami yang mencintainya dalam kehidupan rumah tangga. Status ini sangatlah mulia bukan saja karena memenuhi tuntunan agama tetapi juga dalam pandangan masyarakat yang beradab dan berkesopanan tinggi (Basri, 1999:120).

Dalam hal menjalani pekerjaan, Islam tidak melarang perempuan bekerja di dalam atau di luar rumah secara mandiri atau bersama-sama dengan swasta atau pemerintah, siang atau malam, selama pekerjaan itu ia lakukan dalam suasana terhormat, serta dapat menghindarkan dampak-dampak nagatif dari pekerjaan yang ia lakukan itu terhadap 
diri, keluarga dan lingkungannya (Hartati, 2006:49). Selain itu, ada suatu syarat yang harus dipenuhi adalah mendapatkan ijin dari suaminya, tidak mengganggu kewajibannya sebagai seorang ibu rumah tangga dan juga tidak mendatangkan fitnah baik bagi dirinya sendiri, keluarga, masyarakat, serta agamanya

Berdasarkan teori tersebut jelas bahwa Islam membolehkan perempuan untuk bekerja baik di dalam atau diluar rumah dengan syarat perempuan harus mengerti bagaimana bergaul dengan laki-laki dan harus bisa membagi waktu antara tanggung jawab rumah tangga dengan kepentingan pekerjaannya.

Peran istri dalam membina keluarga Islam terdiri dari membantu suami, membereskan urusan rumah tangga, menggunakan uang secara tertib dan fungsional, menjaga hubungan atau pergaulan sosial yang sehat, menjaga dan mengembangkan hubungan silaturahmi antar keluarga dan sanak famili, memenuhi fungsi istri terhadap suami sebaik-baiknya. (1) Membantu suami. Membantu suami merupakan suatu kenyataan akan kepasrahan dan pengabdian seorang istri terhadap suaminya. Membantu suami bukanlah diartikan karena suami adalah makhluk lemah tiada berdaya dalam kehidupan ini. Suami tetap memerlukan bantuan istrinya dalam beberapa kegiatan dan keadaan yang tidak mampu diselesaikannya sendiri. Beberapa hal yang dilakukan oleh para permpuan yang bekerja sebagai buruh di PT Mangli Djaya Raya dalam bagian membantu suami yaitu bukan hanya pada saat suami kesusahan, melainkan mereka dengan sabar memberikan motivasi dan semangat kepada suami agar seorang suami tidak mudah putus asa dalam menghadapi segala masalah persoalan kehidupan rumah tangga. (2) Membereskan Urusan Rumah Tangga. Tanggung jawab istri adalah mengatur urusan dalam rumah tangga. Seorang istri berkewajiban menjaga dan mengatur rumah tangga supaya suami dan anak-anak krasan tinggal dan berdiam dirumahnya sendiri dengan pengaturannya yang cukup menyegarkan dan memenuhi 
selera kesenangan dalam keluarga. Seorang istri harus bertanggung jawab dengan tugasnya itu, termasuk yang menjadi tanggung jawabnya adalah mengatur urusan-urusan rumah tangga dengan cermat. Kajian yang termasuk pada pengertian mengatur urusan dalam rumah tangga adalah melaksanakan tugas-tugas kerumah tanggaan di rumah seperti menyelenggarakan atau menyiapkan keperluan sehari-hari, membuat suasana rumah tangga menyenangkan dan penuh ketentraman baik bagi suami maupun bagi anak, mengasuh dan mendidik anak-anak dan sebagainya. Dalam hal ini, para perempuan yang bekerja di PT Mangli Djaya Raya ini dalam hal membereskan urusan rumah tangga, meliputi hal-hal yang sehari-hari dilakukan oleh para istri umumnya yaitu mencuci baju, memasak kemudian mengurus anak untuk berangkat ke sekolah. Semua pekerjaan ruah di pagi hari mereka siapkan sejak malam harinya, agar lebih efisien dan menghemat waktu agar pekerjaan rumah selesai sebelum mereka berangkat bekerja. Begitu pula dengan mencuci pakaian, sepulang kerja mereka mencuci pakaian untuk selanjutnya digantung. Barulah pagi hari pakaian-pakaian tersebut dijemur. Jadi, dalam hal ini manajemen waktu yang baik sangat penting bagi perempuan pekerja. (3) Menggunakan Uang Secara Tertib Dan Fungsional. Perempuan di dalam rumah tangga masa kini tidak hanya sekadar menjadi sosok pengasuh, pendidik anak serta mengurus suami dan rumah, tetapi juga haus berperan dalam pengelolaan keuangan keluarga. Sedangkan laki-laki selaku suami memiliki kewajiban menafkahi istri dan anakanaknya dari hasil pekerjaan yang halal, dan sebaliknya istri juga wajib mendapatkan hak dari pendapatan suaminya kemudian mengelolanya dengan baik, tidak berlebihan dan boros. Buruh PT Mangli Djaya Raya bukan digaji per bulan, melainkan 10 hari sekali. Dengan begitu, para perempuan pekerja tersebut harus dapat mengatur keuangan secara maksimal. Bersama dengan pendapatan suami, keuangan keluarga secara tertib dan fungsional dapat mereka lakukan dengan cara digunakan untuk kebutuhan sehari-hari, seperti makanan setiap harinya, membayar listrik 
bulanan, kebutuhan anak sekolah dan sisanya ditabung. Selain itu, para perempuan pekerja ini menginvestasikan sebagian penghasilannya dengan arisan, saat arisan tersebut didapat, biasanya mereka gunakan untuk membeli perabot rumah tangga, uang saku anak, dan kebutuhan lainnya. (4) Menjaga hubungan atau pergaulan sosial yang sehat. Manusia dapat saling mengenal apabila saling berkomunikasi dan bergaul. Pergaulan dapat berjalan dengan baik apabila saling menghormati, saling menyayangi dan saling pengertian antara satu dengan yang lain. Aktifitas sosial ini selalu diperhatikan oleh ibu-ibu yang baik, agar kesalahan yang terjadi bukan hanya menimbulkan penyesalan tetapi kemingkinan menghasilkan akibat yang fatal dan tidak dikehendaki dalam kehidupan. Membentuk dan memelihara pergaulan sosial yang sehat, mengandung makna bahwa isteri perlu berhati-hati dalam kehidupan terutama pergaulan dengan jenis lain yang bukan muhrim. Berdasarkan hasil penelitian terhadap para perempuan pekerja di Desa Petung, mereka membina keluarga sejahtera dengan menjaga hubungan atau pergaulan sosial yang sehat yaitu membagi waktu untuk bersosialisasi dengan keluarga atau tetangga dengan saling tolong menolong, mengikuti pengajian muslimatan yang diadakan seminggu sekali, menjaga ucapan dan tindakan, melayat tetangga yang wafat, serta tidak saling menyakiti baik dengan ucapan maupun perbuatan. (5) Menjaga dan mengembangkan hubungan silaturrahmi antar-keluarga dan sanak famili. rumah tangga muslim adalah rumah tangga yang bermasyarakat. Artinya berhubungan akrab dan saling menghargai sesama warga tanpa membeda-bedakan golongan dan pakat. Sebagaimana sabda Rasulullah yang diriwayatkan Bukhari dan Muslim (dalam Syafe'i, 2000: 206), yang artinya "Anas bin malik r.a berkata, 'saya telah mendengar Rasulullah bersabda, Siapa yang ingin diluaskan rizkinya dan dilanjutkan umurnya, hendaklah menyambungkan hubungan famili (kerabat)". Hadits di atas mengajarkan kepada kita mengenai ganjaran-ganjaran silaturrahmi yang di anugrahkan kepada kita dalam hidup ini, dan yang akan diberikan dalam kehidupan di akhirat. 
Terkait hubungannya dengan ganjaran dunia, ganjaran tersebut diberikan kepada orang yang melakukan silaturrahmi, walaupun ia bukan seorang mukmin. Berdasarkan penelitian, dapat disimpukan bahwa aktivitas perempuan yang bekerja di PT Mangli Djaya Raya Desa Petung ini dalam menjaga dan mengembangkan hubungan silaturrahmi antar keluarga dan sanak famili yaitu untuk dengan memanfaatkan waktu libur bekerja untuk berkunjung atau bersilaturrahmi ke rumah keluarga dan sanak famili. (6) Memenuhi tugas istri terhadap suami sebaik-baiknya. setiap istri wajib menghormati kepemimpinan suami di rumah dan di luar rumah. Karena istri menjadi wakil suami, maka segala tindakan istri dalam mengurus rumah tangga suami, dalam menggunakan uang belanja, mengurus anak dan suami, meminta persetujuan suami apabila melakukan tindakan penting dalam rumah tangga, semua itu harus dipertanggungjawabkan kepada suami. Istri yang baik adalah mereka yang tidak menolak hasrat suaminya yang wajar dan tidak mencari-cari alasan untuk menghindar dari melayani hasrat suami. Para ahli menyimpulkan bahwa sangat besar prosentase perselisihan dan keributan dalam keluarga disebabkan karena ketidakpuasan hubungan antara suami-isteri di tempat tidur (Basri, 1999: 121).

Setiap istri wajib melayani kebutuhan seksual suaminya dan tidak boleh menolak atau menundanya, kecuali karena alasan yang dibenarkan oleh syari'at Islam yaitu haid, nifas, melakukan puasa wajib (Ramadhan) dan menjalankan ibadah haji atau umrah. Terkait dengan hal di atas, berdasarkan hasil penelitian, dapat disimpulkan bahwa perempuan yang bekerja di PT Mangli Djaya Raya ini dalam memenuhi fungsi istri terhadap suami sabaik-sebaiknya yaitu meskipun mereka bekerja untuk membantu perekonomian keluarga, mereka tetap memenuhi kewajibannya sebagai seorang istri seperti; mengurus segala pekerjaan rumah tangga baik mencuci, memasak, dan sebagainya. Serta dalam hal pemenuhan kebutuhan seksual suami, mereka tetap memperhatikan aturan agama yang berlaku sesuai teori di atas. 


\section{Peran Perempuan Pekerja Sebagai Ibu dalam Membina Keluarga Sejahtera}

Selain sebagai seorang istri, peran perempuan juga sebagai seorang ibu. Seorang ibu tidak hanya berhenti ketika dia telah melahirkan dan tuntas dalam pemberian ASI (Air Susu Ibu) pada anak. Akan tetapi peran ibu yang lebih penting adalah proses mendidik anak, yang dalam hal ini adalah mendampingi belajar dan mengawasi perkembangan anak.

Pengertian ini bisa disimpulkan bahwa kedudukan seorang ibu sebagai tokoh sentral, sangat penting untuk melaksanakan kehidupan bagi seorang anak. Pentingnya seorang Ibu terutama terlihat sejak kelahiran anaknya, dia harus memberikan susu agar anak itu bisa melangsungkan hidupnya (Gunarsa, 2008: 31). Sebagai bukti lain, tidak sedikit haditshadits yang menunjukan ketinggian derajat dan kemulian para ibu, antara lain diriwayatkan oleh Bukhari dan Muslim (dalam Najih S: 132) yang artinya: "Dari Abu Hurairah r.a katanya: seorang laki-laki kepada Rosulullah Saw kemudian ia bertanya kepada beliau, siapakah yang berhak atau pergauli dengan baik? Rasulullah SAW menjawab: Ibumu. Dia bertanya lagi, kemudian siapakah? Rosulullah menjawab: Ibumu. Kemudian ia bertanya, kemudian siapa lagi? Rosulullah menjawab: Ibumu. Kemudian ia bertanya, siapa lagi? Rasulullah menjawab: Ayahmu."

Hadits di atas menunjukan bahwa ibu memiliki hak dari anak tiga kali lebih besar dari ayah, kebesaran pahala orang yang sungguh-sungguh berbakti serta berbuat baik kepada ibunya, yang diumpamakan surga itu seakan-akan ada di bawah telapak kakinya. Islam sangat mengutamakan berbuat baik kepada ibu dibanding ayah karena perhatian ibu kepada anak dengan cara mengandung, melahirkan dan menyusui serta tanggung jawab atas segala urusan dan pendidikannya lebih banyak dibandingkan perhatian ayah.

Kendati pun seorang ibu merangkap sebagai pekerja, ia tetap dituntut untuk mendidik dan memperhatikan anak-anaknya, karena ibulah yang pertama kali dikenal dan memberikan pengetahuan kepada anak. 
Seorang ibu juga dituntut untuk mampu memanfaatkan dan meluangkan waktu yang sebaik-baiknya untuk bertemu dengan anak-anaknya.

Adapun beberapa peran perempuan sebagai ibu dalam keluarga serta kaitannya dengan perempuan pekerja di Desa Petung Kecamatan Bangsalsari Kabupaten Jember adalah sebagai berikut: (1) Mengandung, yaitu proses mempunyai keturunan setelah menikah dan merupakan proses melengkapi tugas sebagai seorang perempuan untuk memberikan keturunan yang baik bagi suaminya. Proses berkembang biak merupakan hal yang wajar terjadi pada makhluk Allah yang mulia. Kehadiran seorang anak akan sangat berarti dan akan menambah kehangatan dalam keluarga. Namun seorang anak adalah sebuah amanah yang harus dipelihara dan dijaga. Selain itu, masa mengandung merupakan masa yang penting bagi kehidupan calon bayi. Ahmad tafsir mengutip pendapat Ashley Montagu yang berpendapat bahwa gangguan emosi pada ibu dapat mempengaruhi perkembangan jiwa kandungannya. Dikatakannya bahwa perubahan emosi pada seorang ibu yang menghasilkan perubahanperubahan kimiawi dalam tubuhnya dapat menyebabkan makhluk yang dikandungnya menerima zat-zat kimiawi tertentu yang berlebihan sehingga menyebabkan adanya gangguan pada pertumbuhan dan perkembangan kandungannya (Tafsir, 2010:165). Terkait teori di atas, apa yang dirasakan oleh para perempuan pekerja di Desa Petung adalah rasa bangga ketika mereka sedang melewati masa kehamilan, karena dengan hamil, kesempurnaan seorang perempuan tidak akan diragukan lagi dan para perempuan pekerja sepakat dengan hal tersebut. Kebanggan itu berdampak pada emosi rasa senang mereka. Dapat dikatakan mereka telah menjaga keadaan bahagia tersebut demi kelangsungan janin yang dikandungnya, agar kelak tidak terdapat gangguan terhadap pertumbuhan dan perkembangannya. (2) Melahirkan, yaitu setelah kehamilan adalah melahirkan, tercapai sudah tujuan hidup untuk mempunyai keturunan. Kemudian setelah melahirkan anak disebutlah suami istri sebagai orang tua. Sebagai orang tua haruslah merawat apa yang telah Allah SWT 
berikan padanya sebagai sebuah amanah dalam hidupnya. Sejalan dengan hal tersebut, berdasarkan wawancara dengan responden, mereka mengakui bahwa mempunyai anak adalah sebuah kebanggaan tersendiri, karena hal itu lebih bermakna dari pada kesuksesan di dunia kerja. Kadangkala bagi perempuan pekerja anak adalah motivasi, karena itu dengan kehadiran seorang anak di tengah-tengah keluarga akan semakin menambah motivasi dalam bekerja. (3) Menyusui, yaitu bayi merupakan masa di mana seseorang belum mampu berfungsi secara mandiri (Fathiyaturrahman, 2013: 79). Untuk memenuhi kebutuhan jasmani anak yang masih bayi itu, secara alamiah Allah SWT menciptakan Air Susu Ibu (ASI), yang dipersiapkan bersamaan dengan pertumbuhan janin dalam kandungan. Serentak dengan kelahiran bayi, ASI pun sudah tersedia pada ibu yang melahirkannya itu (Darajat, 1995:480). Umumnya, para perempuan pekerja di PT Mangli Djaya Raya akan mengambil cuti saat menjelang melahirkan. Cuti tersebut berlangsung hingga beberapa bulan setelah melahirkan. Ketika masa cuti tersebut habis, mereka akan kembali bekerja. Saat itu, para perempuan pekerja tersebut masih dalam fase menyusui. Mereka mengatakan, kadangkala sebelum berangkat, mereka sudah menyiapkan ASI di rumah yang disimpan di lemari es. Ada pula yang memberikan susu formula sebagai pengganti ASI saat mereka bekerja. (4) Mendidik Anak, setiap anak dilahirkan dalam keadaan suci (fitrah). Kedua orang tua mempunyai kewajiban untuk memberikan pendidikan kepada anak-anaknya, karena bagaimanapun keadaan seorang anak kelak di masa mendatang tergantung dari didikan orang tuanya. Betapa besar pengaruh pendidikan orangtua terhadap anak-anaknya; ia bisa "menentukan" keadaan anaknya kelak di masa depan. Peran orang tua, terlebih seorang ibu adalah sebagai model tingkah laku yang mudah diamati, pendidik yang memberikan pengarahan, dorongan, pertimbangan bagiperbuatan-perbuatan anak untuk membentuk perilaku, konsultan yang memberikan nasehat, pertimbangan, pengarahan dan bimbingan serta menjadi sumber informasi yang memberikan ilmu pengetahuan, pengertian 
dan penerangan (Gunarso, 2008:235). Dalam hal pendidikan anak, para perempuan di Desa Petung ini lebih memprioritaskan pendidikan formal. Mereka menyekolahkan anak ke sekolah-sekolah yang berkualitas dan tidak terlalu jauh dari tempat tinggalnya. Selain pendidikan di sekolah, masyarakat di Desa Petung juga memasukkan anak-anaknya ke madrasah diniyah untuk belajar agama. Namun dalam hal agama ini, terlebih dulu anak-anak diperkenalkan oleh orang tuanya tentang hal-hal keislaman yang tergolong dasar, misalnya doa-doa sehari hari, adab kesopanan, dan mengajarkan anak sholat serta puasa. Semua itu diajarkan oleh mereka sejak kecil. Sekaligus bertujuan membangun kedekatan orang tua dengan anak.

\section{Simpulan}

Peran perempuan pekerja di PT Mangli Djaya Raya terdiri atas dua peran yaitu sebagai istri dan sebagai ibu. Peran perempuan pekerja sebagai istri tentu terkait hubungannya dengan suami, sedangkan perannya sebagai ibu berhubungan dengan anak. Peran perempuan pekerja sebagai istri dalam membina keluarga sejahtera yaitu sebagai seorang istri, perempuan pekerja PT Mangli Djaya Raya Desa Petung melakukan hal di antaranya saling menghormati antara suami dan istri, taat kepada suami, serta melayani kebutuhan suami sebelum dan pulang bekerja. Meskipun waktu yang dibutuhkan untuk beristirahat kurang memadai, para perempuan pekerja ini juga tetap menjaga keharmonisan dalam bermasyarakat dengan melakukan kegiatan-kegiatan bersama para tetangga dan menjalin hubungan baik dengan kerabat famili di luar kegiatan pekerjaan. Sebagai seorang ibu, para perempuan pekerja di Desa Petung dalam membina keluarga sejahtera dimulai ketika fase mengandung. Mereka menjaga keharmonisan dan kebahagiaan keluarga sebagai jalan untuk menjaga emosi tetap baik, sebab dengan emosi yang baik mereka beranggapan akan berpengaruh baik pula pada calon bayi hingga masa melahirkan. Setelah melahirkan anak, masuk pada masa 
menyusui, pada masa ini para perempuan pekerja ini berusaha mengatur waktu agar bayi mereka tetap mendapatkan ASI sebagai kebutuhan gizi utama bagi setiap bayi.

Memasuki masa kanak-kanak, tugas seorang ibu yang merangkap pekerja juga bertambah. Sebagai orang tua, memberikan pendidikan yang cukup kepada anak merupakan kewajiban. Di samping memberikan pendidikan secara pribadi, keterbatasan waktu seorang perempuan pekerja mengharuskan mereka memasukkan anak ke lembaga pendidikan, baik formal maupun nonformal, baik pengetahuan umum maupun agama, di sekolah dan di tempat mengaji. Kendati pun sibuk, para perempuan pekerja di Desa Petung ini tetap meluangkan waktu untuk memantau perkembangan anaknya.

\section{Daftar Pustaka}

Basri, Hasan.1999. Keluarga Sakinah, Yogyakarta: Pustaka Pelajar.

Darajat, Zakiyah. 1995. Pendidikan Islam dalam Keluarga dan Sekolah. Bandung: Remaja Rosdakarya.

Djamarah,Syaiful Bahri. 2004. Pola Komunikasi Orang Tua \& Anak dalam Keluarga. Jakarta: Rineka Cipta.

Fathiyaturrahmah. 2013. Peran Ibu Dalam Pendidikan Ana., Jember: Stain Jember Press.

Gunarsa, Singgih D. 2008. Psikologi Praktis: Anak, Remaja Dan Keluarga. Jakarta: BPK Gunung Mulia.

Hartati. 2006. Ibu Teladan di Era Global dalam Perspektif Isla. Jakarta: UIN Syarif Hidayatullah.

Najih, Ahmad. Terjemah Riadlus Shalihin. Surabaya: Karya Utama.

Prastowo, Andi. 2011. Memahami Metode-Metode Penelitian. Malang: ArRuz Media.

Sa'adah, Sri Lumataus. 2011. Wanita Karier dalam Perspektif Hukum Islam. Jember: Center For Society Studies. 
INJECT (Interdisciplinary Journal of Communication), Vol.3, No.1, Juni 2018: h. 23-38

Syafe'i, Rahchmat. 2000. Al-Hadis (Aqidah, Akhlak, Sosial, dan Hukum). Bandang: Pustaka Setia.

Sudarsono. 1991. Hukum Kekeluargaan Nasional. Jakarta: Rineka Cipta.

Tafsir, Ahmad. 2010. Ilmu Pendidikan dalam Perspektif Islam. Bandung: Remaja Rosdakarya. 